\section{Betting on an inexact science}

\section{San Francisco \& Tokyo}

DESPITE all the uncertainties of earthquake prediction, the state of California this month took the daring step of producing a detailed plan for warning the public of imminent earthquakes. The plan is the first to be developed in the United States, although an early warning system based on the advice of expert seismologists has been operating in Japan for more than ten years. Issued by the Governor of California's Office of Emergency Services, the 140-page Short-Term Earthquake Prediction Response Plan lays out how to let millions of citizens know of an increase in the chance of an earthquake in the following 72 hours, and what specific safety precautions communities should take.

The new system provides the best use of current scientific knowledge for public policy purposes, says James Davis, the California state geologist and chairman of the California Earthquake Prediction Evaluation Council (CEPEC). Although some California seismologists say they feel After-effects of earthquakes - predicting the unpredictable. uncomfortable at being forced to discuss the technicalities of their field in public, they generally accept the plan as a reasonable bridge between an inexact science and public policy. But they continue to stress that they are unable to predict earthquakes. Rather, scientists can identify only heightened probabilities of damaging earthquakes in the coming few hours or days because the dataset of clear short-term warning signals is still tiny.

According to the state's plan, shortterm predictions of increased seismic activity, which would almost certainly come from the US Geological Survey, are evaluated by CEPEC. The council, consisting of ten seismologists and geologists, convenes quickly, probably by conference call, and determines whether the observations merit a public warning from the Office of Emergency Services. The warnings will allow city and county governments to take precautions such as activating emergency shelters, alerting reserve emergency workers and evacuating high-risk buildings.

In addition, CEPEC has pre-approved statements that are to be issued in case of various earthquake events in the heavily monitored region of the San Andreas fault near Parkfield in central California. A moderate earthquake is expected there very soon, judging from past seismic patterns. A similar pre-approval warning system is being developed for the southern part of the San Andreas fault.

In a less formal manner, the state has actually issued five earthquake advisories since 1985, including two for the Loma Prieta region of the San Andreas fault, the However, the second of those five-day advisories came two months before the magnitude 7.1 earthquake, much too early to help.

Although the United States has a National Earthquake Prediction Evaluation Council, that organization focuses on longer-term forecasts for regions throughout the country. Japan, however, has a

\section{IMAGE UNAVAILABLE FOR COPYRIGHT REASONS} complex national early warning plan in place. In the event of possible earthquake precursor activity, the Japan Meteorological Agency (JMA) whisks a committee of six experts to its Earthquake Assessment Committee Room in Tokyo within one hour. Members of the committee carry pocket pagers at all times and are not allowed to go out of pager range without informing the agency.

If a major earthquake is deemed imminent by the committee, the director general of the JMA flashes a message to the office of the prime minister, who then issues a warning to the nation. The Japanese then prepare emergency supplies, make buildings ready, and take cover or evacuate, according to plans rehearsed in annual earthquake drills.

Although the committee has met several times for practice, it has yet to issue an actual earthquake warning. And at least one Tokyo University geophysicist suspects that the aim of the whole complex warning system is to diffuse responsibility among as many scientists, bureaucrats and politicians as possible in case it does not work. All seismologists know that earthquakes can seldom be predicted, he says, but they cannot say that too loudly for fear that the $¥ 1,800$ million ( $\$ 14$ million) a year in funds for earthquake prediction would dry up.

Elizabeth Schaefer \& David Swinbanks site of the October 1989 earthquake.

\section{Don't look now . . .}

\section{Washington}

AFTER a summer of US Department of Energy (DoE) press conferences designed to detail every step of the Superconducting Super Collider (SSC) project's redesign, DoE deputy secretary Henson Moore finally let the bad news slip out last week at a poorly attended signing ceremony in Texas. The latest estimate is that SSC will cost $\$ 8,244$ million and take until 1999 to complete, a dramatic change from Moore's brave declaration of three months ago that "we're going to hold the contractor to $\$ 7.8$ billion and to finish by 1998 " (Nature 356,401; 2 August 1990).

What made Moore swallow his words, says a DoE spokesman, is that "the [DoE] review groups said that was too aggressive a funding profile", given congressional budget restraints. All of this, however, is news to Congress. Although last month's budget language directs DoE to serve up an SSC cost estimate "immediately", DoE now says that the White House will not let it report formally the new figures until after the president's 1992 budget request in January. Congress is unlikely to take the snub kindly. "We asked for a number and we didn't get one. They've got to come to us for another budget next year", an appropriations staff member hints darkly. Christopher Anderson

\section{Exiled writer refuses post \\ Cape Town}

The University of the Western Cape (UWC)'s vice-rector-designate, Professor Njabulo Ndebele, last week informed the university that he will not now be taking up the post. The appointment of Ndebele, who has lived in exile as the president of the Congress of South African Writers created an uproar in April when the government refused to grant him a work permit (see Nature 344,581 \& 345,$284 ; 1990)$. In a statement released last week, the Rector of UWC, Jakes Gerwel, criticized the government, saying that he had no doubt that it had contributed to pressures on Ndebele. Ndebele still intends to return to South Africa, but is now seeking employment in Johannesburg. Michael Cherry

\section{Happy ending?}

London

THE long-running dispute at the Natural History Museum in London may have been resolved now that all the researchers threatened with redundancy have been found alternative employment within the museum. A spokesman from the scientists' trade union, the Institution of Professionals, Managers and Specialists (IPMS) intimated last week that such a situation would be seen as an "acceptable olive branch".

Henry Gee 